\title{
STUDI PENDUDUKAN ACEH DALAM DE ATJEHERS
}

\section{Syaifullah Amin}

Direktur Aswaja TV

\section{PENDAHULUAN}

Saya rasa, kita sependapat untuk menempatkan Cristian Snouck Hurgronje ${ }^{1}$ dalam daftar teratas para indonesianis yang berkiprah untuk menyelidikidan mendefinisikan Islam dan Nusantara pada masa kolonialisme Belanda. Karir indonesianisnya dimulai pada $\underline{1889}$ ketika dia menginjakkan kaki di pulau Jawa, dan mulai meneliti pranata Islam di masyarakat pribumi Hindia- Belanda, khususnya Aceh. Setelah Aceh dikuasai Belanda tahun 1905, Snouck mendapat penghargaan yang luar biasa. Setahun kemudian dia kembali ke Leiden, dan sampai wafatnya, 26 Juni 1936, dia tetap menjadi penasehat utama Belanda untuk urusan penaklukan pribumi di Nusantara. ${ }^{2}$ Sosok Snouck, bagi Belanda, adalah pahlawan yang berhasil memetakan struktur perlawanan rakyat Aceh. Bagi kaum orientalis, dia sarjana yang berhasil. Tapi bagi rakyat Aceh, dia adalah pengkhianat tanpa tanding. Sebagai seorang orientalis, ia menyusup dalam kekuatan rakyat Aceh, memanipulasi tugas keilmuan untuk kepentingan politik.

Meski bukan Hurgronje bukanlah seorang orientalis dan sekaligus indonesianis

\footnotetext{
1 Christiaan Snouck Hurgronje (1857-1936) lahir pada 8 Februari 1857 di Tholen, Oosterhout, Belanda. Seperti ayah, kakek, dan kakek buyutnya yang betah menjadi pendeta Protestan, Snouck pun sedari kecil sudah diarahkan pada bidang teologi. Tamat sekolah menengah, dia melanjutkan ke Universitas Leiden untuk mata kuliah Ilmu Teologi dan Sastra Arab, 1875. Lima tahun kemudian, dia lulus dengan predikat cum laude dengan disertasi Het Mekaansche Feest (Perayaan di Mekah). Tak cukup bangga dengan kemampuan bahasa Arabnya, ia melanjutkan pendidikan ke Mekkah, 1884. Di Mekkah, keramahan dan naluri intelektualnya membuat para ulama tak segan membimbingnya. Dan untuk kian merebut hati ulama Mekkah, Snouck memeluk Islam dan berganti nama menjadi Abdul Ghaffar. Snouck Hurgronje menulis tidak kurang 1400 karangan mengenai Aceh dan Islam di Indonesia. Dialah juga yang kemudian memberikan nasehat kepada pemerintah kolonial Belanda dalam menaklukkan kerajaan Aceh. Bersama Cornelis van Vollenhoven (1874- 1933), seorang perumus hukum adat Indonesia, dia menjadi peletak dasar studi Indologi di Universitas Leiden. Tak berlebihan jika dikatakan bahwa Snouck adalah seorang ideolog yang mekonstruksikan pemahaman terhadap bangsa-bangsa di kepulauan Nusantara.

${ }^{2}$ Selain tugas memata-matai Aceh, Snouck juga terlibat sebagai peletak dasar segala kebijakan kolonial Belanda menyangkut kepentingan umat Islam. Atas sarannya, Belanda mencoba memikat ulama untuk tak menentang dengan melibatkan massa. Tak heran, setelah Aceh, Snouck pun memberi masukan bagaimana menguasai beberapa bagian Jawa dengan memanjakan ulama. Peran mata-mata ini dengan sempurna dilaksanakan Snouck, seorang antropolog dan sosiolog yang paling kesohor sepanjang sejarah itu. Sekali lagi, seberapa pun besar biaya yang dikeluarkan atas nama Snouck untuk memerangi Aceh, tentu tidak sebanding dengan keuntungan yang diperoleh; Aceh dikuasai.
} 
pertama yang mengkaji tentang Aceh, namun ia terbukti mampu bergerak lebih jauh. Snouck melakukan penelitiannya demi menumpas para pemberontak Muslim di Hindia Belanda. Seorang sosiolog Belanda, Wim F. Wertheim berkesimpulan bahwa Snouck merupakan aktor intelektual dalam penyusunan strategi perang anti gerilya (counter insurgency) dalam fase kedua perang Aceh (1873-1904) jauh sebelum Amerika Serikat mendanai berbagai proyek serupa di Vietnam pada tahun 1970-an. Ia juga tercatat sebagai tokoh yang pertama kali menggulirkan wacana perlunya pembakuan bahasa Indonesia dan pengaturan batas usia perkawinan bagi warga pribumi. Politik etis yang selama ini dinyatakan sebagai balas budi atas Tanam Paksa, konon juga dijalankan atas usulan Snouck.

Hingga hari ini, setelah sederet nama besar mengkaji karyanya tentang dunia Islam terutama Aceh, masih hidup dengan perasaan curiga dan tidak puas. Bahkan, pada tingkat tertentu sempat dipertanyakan soal moralitas pribadi Snouck, termasuk prosesi pemakamannya yang sama sekali mengabaikan sisi "keislamannya". Seolah-olah tak pernah terjadi apa-apa. Sayangnya, selama ini studi, kepustakaan, hasil kajian dan tulisan tentang Snouck Hurgronje lebih banyak ada di Belanda, ${ }^{3}$ bukan di Indonesia. (harap maklum! Mengerti sendirilah, bagaimana perhatian pemerintah).

Baiklah, marilah kita sejenak kita tengok kiprah Snouck dalam pengaruhnya di masyarakat Aceh era kolonial paska penyerbuan militer belanda. Di mana Pengamatan Snouck sebenarnya sudah dimulai saat ia berada di Mekkah, kota yang mampu memompa darah segar Islam di Hindia Belanda. ${ }^{4}$ Dia pun tercengang melihat orang

\footnotetext{
${ }^{3}$ Pusat Studi Islam di Universitas Leiden sudah sangat tua bahkan berdirinya hampir bersamaan dengan berdirinya universitas ini pada tahun 1575. Jadi sejak lama, kaum cendekiawan Belanda sudah memberikan minat pada studi Islam dan Arab. Ketika Belanda menjajah Indonesia, mereka banyak berhadapan dengan unsur unsur Islam dan berperang dengan tentara kerajaan Islam di Indonesia. Keadaan ini membuat Pusat Kajian Islam Universitas Leiden membuka pusat pelatihan bagi pegawai negeri yang akan dikirim ke Hindia Belanda. Mereka diberi pengetahuan mengenai Islam dan aspeknya termasuk hukum dan adat istiadatnya. Universitas Leiden adalah universitas tertua di Belanda dan didirikan pada tahun 1575 oleh Pangeran William of Orange sebagai hadiah bagi warga Leiden atas kegigihan mereka mempertahankan Leiden dari penjajahan Spanyol. Mungkin banyak yang belum tahu, selain menjajah Indonesia, Belanda ternyata juga dijajah oleh bangsa Spanyol diabad 16. Namun bagi banyak orang, yang menarik dari Universitas Leiden ini bukan sejarahnya, tetapi Pusat Kajian Islamnya, yang sudah berdiri sejak Universitas ini ada. sekarang pusat Kajian Islam diketuai oleh Dr. Nico JG Kaptein sebagai pengarah.

${ }^{4}$ Penelusuran Snouck mengenai hubungan antara penduduk Nusantara dan Mekkeh dapat ditelusuri melalui karya-karyanya tentang Arab, jamaah haji dan Perang Suci. Misalnya adalah karyanya mengenai Para Jamaah Haji dan Peperangan yang dimuat di Nieuwe Rotterdamsche Chourant 24 dan 25 November 1915.
} 
Arab sering memperbincangkan Perang Aceh. Orang Aceh cukup banyak dan begitu fanatik dalam melawan Belanda. Ia ingin sekali menyumbangkan usulan ilmiah kepada pemerintah guna menundukkan Aceh. Hal yang segera disampaikan kepada pemerintah Belanda, adalah mengusahakan pemisahan Islam dan politik di negeri jajahan. Para jamaah haji diawasi, karena berpotensi membawa ide pan-Islamisme ke Aceh yang sangat bertentangan dengan kepentingan Belanda. Snouck menggambarkan bahwa:

Lama sebelum kepulauan Nusantara jatuh di bawah jajahan pemerintah Belanda, sudah banyak kaum pribumi yang melakukan ibadah haji. Bahkan sudah sejak berabad-abad di Mekah ada kelompok pribumi Nusantara yang jumlahnya selalu bertambah, baik yang bermukim di sana untuk sementara waktu maupun sepanjang hidupnya; untuk mempelajari ilmu agama atau sekedar agar dapat hidup dekat di Baitullah.....

Orang dapat membayangkan betapa janggalnya kesan yang diperoleh orang-orang Jawa, Melayu dan seterusnya yang menyaksikan kejadian-kejadian semacam itu. Di dalam diri mereka timbullah pikiran bahwa pemerintahan di negerinya sedang menghadapi penghinaan besar dan bahwa mereka harus menerima saja.....

Bahwa para jamaah di kota suci tidak dibiarkan terancam oleh usaha-usaha untuk mengadakan pemberontakan terhadap pemerintah yang menguasai mereka, dan bahwa konsul, sebagaimana dulu, dapat memberikan perlindungan yang diperlukan dan dapat melakukan pengawasan tanpa dihalangi oleh pihak penguasa setempat......

Di sisi lain Snouck tampaknya berhasrat untuk membuktikan keunggulan perkembangan peradaban Kristen di Eropa, dibanding peradaban Islam, Yahudi, Buddha, Hindhu, Tao dan Konfusianisme yang terpaku pada solidaritas komunal. Di mana Islam ditempatkan pada porsi utama untuk menunjang kepentingan imperium kolonialis dalam mematahkan kekhalifahan Ottoman di Turki atas negeri-negeri di Asia Barat dan Afrika. Juga hasrat untuk menundukkan bangsa-bangsa yang hidup di Asia Tenggara dan Selatan. Untuk tujuan yang pertama melaporkan karya- karya mengenai Arab dan Turki, di antaranya adalah mengenai, Tarekat Agama, Mekah dan Pan Islamisme 1900; Kekhalifahan Sultan Kostantinopel 1901; Larangan Sekulerisme di Hadramaut 1905; Turki Muda, Kenang-kenangan dari Istanbul 25 juli-23 September 1908; Perang Suci ”Buatan Jerman” 1915; Perang Suci dan Penyebaran Agama 1915;

\footnotetext{
${ }^{5}$ Nieuwe Rotterdamsche Chourant, 25 November 1915.
} 
Para Jamaah Haji dan Peperangan 1915; dan lain-lain. ${ }^{6}$

Dari karya-karyanya tersebut kita dapat membayangkan, betapa kecerdikan dan kesempatan yang dimilikinya telah mengantarkannya untuk menjadi seorang ahli tentang Islam dan Arab yang mumpuni. Dalam hal ini, iklim intelektual Eropa sangat mendukung. Di mana sejak abad pertengahan, bahasa dan kebudayaan Arab telah dipelajari di Eropa. Meski secara umum fokus perhatian masih terbatas pada naskahnaskah, khususnya naskah filsafat, sejarah, dan geografi; artinya hukum Islam sama sekali tidak dipelajari karena dianggap kering, tidak menarik. Namun pandangan semacam ini tidak berlaku bagi Snouck. Menurutnya, pengertian ilmiah mengenai Islam hanya dapat diperoleh dengan cara mempelajari hukum Islam dan bagaimana hukum Islam itu dipraktikkan oleh umat Islam dalam kehidupan sehari-hari, "Volledige beheersing van de schriftelijke bronnen, gepaard aan omvattende kennis van de levende werkelijkheid”. Menguasai sepenuhnya semua sumber tertulisnya harus juga disertai pengetahuan yang lengkap mengenai realitas yang hidup.

Tokoh ini membangun tesis bahwa, seperti halnya dalam kehidupan individu, dalam kehidupan masyarakat pun unsur- unsur religi berbaur dengan unsur-unsur sosial lainnya, terkait erat tak terpisahkan. Sehingga siapapun yang ingin menyelami faktor Islam dalam kehidupan suatu bangsa secara mendalam, harus mengetahui pula aspek keseharian masyarakatnya. Selain melihat Islam sebagai identitas komunal, ia menganggap sangat penting aplikasi setiap individu masyarakat sebagai bentuk aplikasi kepercayaan mereka.

Dalam kasus Aceh, Snouck yang menginjakkan kaki secara legal pertama kali ke Aceh pada 6 Juli 1891 memiliki makna ganda. Perspektif orientalisme mengindikasikan bahwa kehadirannya adalah kesempatan untuk menyingkap lebih luas mengenai apa dan bagaimana sesungguhnya Aceh, khususnya bagi kacamata kolonial. Sementara dari perspektif permasalahan di Aceh pada zamannya, kehadiran Snouck Hurgronje menandai era baru bagi perang yang telah berlangsung hampir 20 tahun tersebut.

Pengetahuannya yang demikian berpengaruh dalam pengambilan kebijakan pemerintah kolonial pada masanya, tak dapat dilepaskan dari pengamatannya tentang

\footnotetext{
${ }^{6}$ Lihat: Verspreide gheschriften van C. Snouck Hurgronje, Kurt Schoeder,1923
} 
Negeri paling Ujung Indonesia ini yang sudah dimulai saat ia masih berada di Mekkah. Di mana ia tercengang menyaksikan orang-orang Arab sering memperbincangkan Perang Aceh. karenanya, ia ingin sekali menyumbangkan usulan ilmiah kepada pemerintahnya guna menundukkan Aceh. Maka, hal yang segera disampaikan kepada pemerintah Belanda, adalah mengusahakan pemisahan Islam dan politik di negeri jajahan. Para jamaah haji diawasi, karena berpotensi membawa ide Pan-Islamisme ke Aceh yang sangat bertentangan dengan kepentingan Belanda. Kemudian Selama tujuh bulan berada di Aceh, ${ }^{7}$ Hurgronje dibantu beberapa orang pelayannya untuk memberi masukan dan membuat pelaporan (Verslag) kepada pemerintah Belanda tentang budaya dan keagamaan, dalam lingkup nasehat strategi kemiliteran.

Rekomendasi-rekomendasi ini berangkat dari hasil penelitiannya tentang masyarakat Aceh, yang diakuinya atau tidak, bagi mereka berarti timbulnya "warna baru" dalam penderitaan panjang bangsa jajahan.

Khusus mengenai Aceh, kita dapat menelusuri laporan- laporan Snouck melalui setidaknya dua dari dari tiga jilid Aceh Verslag, ${ }^{8}$ yang kemudian diterbitkan secara berurutan pada tahun 1893 dan 1894 dalam bentuk buku yang berjudul De Atjehers. ${ }^{9}$ Buku yang dipuji sebagai magnum opus-nya ini tampaknya lebih mengarah untuk konsumsi para pembaca Eropa. Karenanya, dia memberikan cukup percaya diri untuk mengesankan bahwa rakyat Aceh dan penduduk Nusantara pada umumnya sebagai manusia yang memiliki sifat licik, kotor, ingkar janji dan tidak memiliki keunggulan berpikir. Dari sini ia mengajak pembaca Eropa membandingkan penduduk Nusantara dengan kelas menengah Eropa.

Tak aneh bila dalam karya monumentalnya, The Acehnese De Atjehers yang telah diterjemahkan dan diterbitkan dalam bahasa Indonesia oleh IndonesianNederlands Cooperationin Islamic Studies (INIS) tahun 1998, Sekretaris Pemerintah

\footnotetext{
${ }^{7}$ Sekitar tujuh bulan kemudian Snouck kembali ke Batavia. Pekerjaannya bertambah menjadi Penasihat urusan Pribumi dan Arab. Lembaga yang didirikan 1899 ini dapat bisa dipandang sebagai cikal bakal Departemen Agama.

${ }^{8}$ Laporannya yang panjang ini 23 Mei 1892 diserahkan kepada Gubernur Jenderal Pijnacker Hordijk pada 23 Mei 1892. judul Aslinya adalah Verslag omtrent de religieus-politieke toestanden in Atjeh, kemudian dibukukan dengan judul De Atjehers (1893/1894). Terjemahannya dalam bahasa Inggris muncul tahun 1906 dengan judul The Acehnese.

${ }^{9}$ Sebuah buku lain yang membedakan antara pelaporan Snouck mengenai orang-orang sekitar Banda, Aceh Besar dan Kutaraja dengan penduduk pantai barat Aceh adalah Het Gajoland (Orang-orang Gayo) yang juga telah diterbitkan oleh INIS.
} 
C.B. Nederburgh, memberikan sebuah pengumuman bahwa :

Meskipun pemerintah mengambil prakarsa untuk menerbitkan karya ini sebagai sumbangan atas permasalahan yang berarti penting dan aktual, namun karena sifat polemiknya yang dijumpai dalam argumentasi, rasanya berlebihan untuk menyatakan, bahwa isi karya ini sampai ke soalsoal kecil memberikan anggapan seolah-olah disetujui olah pemerintah. ${ }^{10}$

Buku yang diterbitkan dalam bahasa Indonesia dengan judul, Aceh; Rakyat dan Adat Istiadatnya, ini memberikan gambaran kepada kita mengenai masyarakat Aceh dan kultur yang berkembang pada saat itu. Tentu saja, dengan demikian karya ini mengandung intensitas bias yang cukup tinggi, mengingat Snouck adalah seorang penasehat pemerintahan yang sangat menentukan kebijakan-kebijakan pemerintah pada masa penguasaan Belanda atas tanah rencong tersebut.

Dalam kata pengantarnya, Snouck menuliskan :

Karya yang kini anda hadapi, dapat dianggap sebagai hasil tugas yang diberikan oleh Yang Mulia Gubernur Jenderal Hindia Belanda, yaitu pengolahan yang amat luas dari bagian pertama Verslag omtrent de religieus-politieke toestanden in Aceh (Laporan tentang keadaan agama dan politik di Aceh) yang saya serahkan pada 23 Mei 1892 dan datanya saya kumpulkan selama bermukim di Aceh dari Juli 1891 sampai Pebruari 1892.

bila benar-benar ingin mendalami faktor Islam eksistensi bangsa, maka permainan anak-anak, kesenangan orang-orang tua, literatur tidak sopan, tata desa dan propinsi, dalam banyak segi sama pentingnya dengan buku yang dipakai pada pendidikan agama, perkumpulan mistik yang melakukan propaganda di wilayah ini dan ahli hukum. Jika di samping itu, hal-hal yang lebih asusila di Aceh masih tidak begitu dikenal, tidak ada alasan kalau kadang-kadang meminta supaya tiap-tiap tema penyelidikan ditangani oleh seorang ahli, dan penelitian saya ini diungkapkan kepada publik. ${ }^{11}$

Dalam buku ini, Snouck membagi laporannya dalam tiga bab di jilid I dan tiga bab di jilid II. Pada bab Pertama jilid I, adalah Pembagian Penduduk, Bentuk Peradilan dan Pemerintahan. Bab kedua menceritakan tentang Penanggalan, Perayaan, Musim, Pertanian, Pelayaran dan Perikanan, dan Hukum Tanah dan Air di Aceh. Sementara dalam bab ketiga, ia memaparkan tentang Kehidupan Keluarga dan Hukumnya.

\footnotetext{
${ }^{10}$ Snouck Hurgronje, Aceh Rakyat dan Adat Istiadatnya, dalam Pengumuman, INIS 1998.

${ }^{11}$ Snouck, De Atjehers, dalam Kata Pengantar, INIS
} 
Padabab pertama misalnya, Snouck di antaranya menjabarkan mengenai sejarah Aceh besertabatas wilayahnya-yang disebutnya sebagai "kerajaan segi tiga", asal-usul rakyat, perkampungan dan tradisinya, yang meliputi, gampong, meunasah, ibadah, dayah, penghasilah keuchik, tengku dan hukum adat. Uleebalang dan susunannya serta pertikaian-pertikaian antara para penguasa tradisional; para petualang politik dan wakil agama. Dalam bab ini ia juga memaparkan pendapatnya mengenai ulama-ulama Aceh yang "gemar beristirahat" namun sewaktu-waktu dapat saja menyulut perlawanan kepada pemerintah kolonial karena tidak ingin kehilangan kekuasaannya sama sekali, baik di hadapan pemerintah pendudukan maupun di depan rakyatnya sendiri. ${ }^{12}$

Sedangkan pada jilid II bab pertama, Snouck melaporkan pengetahuanpengetahuan yang berkembang di Aceh, yang terbagi dalam praktek tigabagian ilmu pengetahuan Islam dan studi persiapannya; mistik, bid'ah dan pemberantasannya; tingkatan ilmu pengetahuan; sekolah-sekolah dan kehidupan para siswa; dan kesenian setempat. Pada $b a b$ kedua ia mengulas tentang kesusastraaan, yang membeberkan tentang cerita-cerita, bentuk kesusastraan tulis, hikayat-hikayat, risalah asli, ceritacerita roman, dan dongeng binatang serta karya-karya keagamaan. Literatur keagamaan ini dipisahkan oleh Snouck dalam dua babak sejarah, yakni era pra Islam dan zaman Islam, serta beraneka epos kepahlawanan dan hikayat-hikayat. Sedangkan di bab ketiga ia melaporkan kegemaran-kegemaran rakyat Aceh, aneka bentuk permainan dan hiburan anak-anak, musik dan contoh-contoh nyanyian, serta bentuk-bentuk pawai dan macam-macam pesta rakyat Aceh.

Akan tetapi tampaknya Snouck tidak benar-benar memperhatikan keseniankesenian Aceh, terutama terhadap benda- benda mulia. Secara keseluruhan diperoleh kesan bahwa, dalam anggapannya jiwa seni rakyat Aceh amat rendah. Meskipun ia mengakui bahwa di masa kejayaan kerajaan pelabuhan, semaraknya pergaulan dengan orang-orang non Aceh menyebabkan berbagai produk kesenian memasuki wilayah tersebut, terutama di kalangan bangsawan. Akan tetapi, menurutnya, jiwa menyenangi seni ini lekas surut seiring kemunduran politik Aceh. Bahkan pengaruh peradaban "asing" (Islam) yang paling lama berpengaruh pada mereka pun tak banyak menolong dan membangkitkan minat ke arah ini.

\footnotetext{
${ }^{12}$ Snouck, De Atjehers, h. 142
} 
Sementara dalam laporan-laporannya yang lain mengenai Aceh -yang tidak terdapat dalam buku ini- beberapa di antaranya tampak bahwa Snouck harus berselisih dan beradu argumentasi dengan Joh. S.A. van Dissel yang mengutip karya Van Langen, Atjineesche Spraakkunst (tata bahasa Aceh), ${ }^{13}$ dengan menyatakan bahwa Dissel sebenarmnya kurang mampu memahami bahasa dan sastra Aceh. ${ }^{14}$

Dalam penilaian Snouck, cerita-cerita rakyat Aceh yang berkembang pada masanya, sangat jauh dari kebenaran. Karena menurutnya, cerita-cerita tersebut hanyalah "dikarang", bukan "ditulis". Oleh karena perbedaan antara segala sesuatu yang "diabadikan" dan "tidak diabadikan" melalui tulisan, maka sangat sulit untuk menerapkan dasar secara taat pada karya- karya para pengarang Aceh. Bahkan menurutnya, karya- karya Aceh sekalipun tertulis tidak dapat diselamatkan dari pengubahan-pengubahan setelah turun-temurun disalin dalam beberapa generasi. Setiap orang penyalin dapat sekehendak hati menambahkan imaji-imajinya sesuai seleranya masing-masing bahkan dianggap sebagai penyalin yang bodoh dalam bidang sastra jika sang penyalin sama sekali tidak memberikan perubahan dalam objek. Karenanya, meskipun telah mengenal aksara Arab, masyarakat Aceh -waktu itu-masih tergolong masyarakat dengan tradisi lisan yang dominan. Snouck mengalami kesulitan merekam berbagai bentuk cerita rakyat, namun kendala ini teratasi dengan bantuan Tengku Muhammad Nurdin. Di mana pencatatan dan perekaman membutuhkan standardisasi ejaan dan ortografi, sehingga Snouck menganjurkan perlunya pembakuan ejaan bahasa Indonesia. Kajian kebudayaan yang dilakukan Snouck kemudian terlihat dari rekonstruksi Sejarah Kerajaan Aceh hingga perempat pertama abad XVIII (1911). ${ }^{15}$

Snouck rupanya, agak malas mengulas syair-syair Aceh, kendati ia mencantumkannya dalam laporan-laporan berkalanya, baik yang kemudian turut tersusun dalam The Acehnese maupun bukan. Dalam pandangannya, adalah kesia-siaan belaka untuk lebih banyak detail mengenai sifat sastra Aceh. Bagaimanapun, di dalamnya hanyalahberisi tentang fantasi bebas yang dikemukakan penyair melalui

\footnotetext{
13 Laporan ini dimuat dalam Bijdragen van het Koninklijk instituut voor de Taal-, Land-en Volkenkunde van Nederlandsch- Indie, 1890. h. 504-516

${ }^{14}$ Weltevreden, De Indische Gids, Leiden 1893.

15 Dalam beberapa hal Snouck memperkuat argumentasi ini dengan dengan mencontohkan bahwa beberapa di antara para penyalin tersebut adalah teman-temannya.
} 
tokoh-tokoh eposnya sendiri, serta banyak sekali kejadian-kejadian "boros" yang diambil dari kehidupan rakyat Aceh untuk disisipkan ke dalam ceritanya. Karena tidak mungkin memastikan bagaimana kenangan yang disajikan sebagai fakta yang fantastis, yang sangat jauh menyimpang dari berita sejarah terpercaya, dapat dijadikan landasan meneliti detail-detail sifat sastra (dalam epos-epos kepahlawanan).

Argumentasi yang diyakininya sebagai fakta sejarah adalah bahwa Sultan Iskandar Muda pernah menahlukkan beberapa bagian semananjung Malaya seperti Johor (1613) dan Pahang (1618). Sehingga Aceh pernah memiliki kekuasaan yang setara dengan kekuasaan Portugis yang datang ke Malaka seabad lebih dahulu. ${ }^{16}$ Meski beberapa kali Iskandar Muda beberapa kali berusaha mengusir Portugis dengan armada laut yang sangat besar, di antaranya adalah peperangan yang terjadi pada tahun1628, namun semua usaha itu tidak pernah memberikan hasil, walaupun sebenarnya saingannya ini telah terdesak. ${ }^{17}$

Hurgronje, dalam hal ini berusaha menertawakan kesalahan para penyair Aceh yang menganggap bahwa orang-orang Malaka yang yang di serang oleh Aceh. Digambarkan sebagai orang-orang kafir yang bersarang dari Guha (Portugis yang mendirikan benteng di Goa). "Sesungguhnya tidak mungkin memastikan bagaimana kenangan yang disajikan kepada kita sebagai fakta yang fantastis; begitu jauh gambaran menyimpang dari kabar sejarah yang dapat dipercaya."18 Ia bahkan mengecam beberapa peristiwa yang tergambar melalui syair-syair sebagai sifat khas ekspedisi perang Aceh; kerena pemimpin maupun bawahan tidak mengurus perbekalan pasukan dengan cukup, ketika pasukan melintas di suatu kampung adalah bencana bagi penduduk. Kebun tebu yang dijumpai, habis ditebas pasukan dan sisanya diperebutkan oleh para prajurit yang masih hasu dan lapar. Termasuk kebiasaan konvoi untuk merampok pasar-pasar yang dilaluinya. Lemahnya kontrol terhadap pasukan pribumi memungkinkan terjadinya kekacauan akibat ulah beberapa prajurit yang tidak tahan terhadap godaan untuk menjarah gudang, dagangan dan bahkan pakaian yang melekat pada para pedagang keling.

Beberapa legenda (epos kepahlawanan yang disebutnya sebagai fiksi aneh)

\footnotetext{
${ }^{16}$ F. Falentijn, Oud enView Oost-Indien dalam Beschrijvingen van Sumatera.

${ }^{17}$ Seabad kemudian, Dipati Unus (Pangeran Sabrang Lor) dari Demak juga melakukan usaha pengusiran Portugis dari Malaka, namun pasukan kerajaan Islam Jawa ini juga mengalami kegagalan.

${ }^{18}$ Snouck, De Atjehers, II: 63-77
} 
Aceh yang mengisahkan perjalanan Sultan Mahkota Alam -Meukuta Alam, gelar yang diberikan kepada Eseukanda/Iskandar setelah meninggal- melawan Malaka dalam fabel-fabel perjalanan laut, menyadarkan Snouck bahwa meskipun memiliki banyak musuh bangsa Eropa, namun orang-orang Aceh lebih melihat penguasa Belanda sebagai musuh utama melebihi Portugis maupun Inggris. Pada saatnya, bangsa Portugis telah sepenuhnya keluar dari lingkaran pandangan Aceh, sedangkan kafir-kafir Belanda merupakan lambang dari segala bahaya, yang mengancam Aceh dari pihak Eropa. Atas amatannya inilah, tampaknya ia lebih tertarik untuk meneliti tentang peran dan pengaruh agama (Islam) dalam kehidupan politik di Aceh. Dalam pengantar De Atjehers, Snouck menuliskan :

Tujuan utama penelitian saya adalah untuk mencari pengetahuan mengenai pengaruh Islam dalam kehidupan politik, sosial dan agama rakyat Aceh. Ketika bermukim di Arabia, di mana saya sangat banyak bergaul dengan orang Aceh -rumah saya di Mekah berhadapan dengan rumah salah seorang syekh bangsa Aceh- semacam hotel yang saya kunjungi hampir tiap hari; itu memang sangat membantu saya dalam pekerjaan, namun demikian

untuk bergaul dengan orang Aceh di daerahnya sendiri, diperlukan pemahaman ungkapanungkapan terpenting dalam kehidupan mereka. ${ }^{19}$

Dari sinilah kemudian Snouck lebih memprioritaskan pekerjaannya untuk mengamati peranan para pemimpin masyarakat Aceh. Ia mempelajari persinggunganpersinggungan yang sering muncul dalam interaksi sosial di antara para Uleebalang dan para Habib keturunan Arab. Antara para sultan dengan kelompok- kelompok mandiri dan para ulama yang memihak Belanda. Seorang Teolog yang juga temannya, Theoder Noldeke, menyatakan bahwa perjalanan Snouck memiliki dua tujuan. Pertama, tujuan ilmiah. Snouck dengan mudah mendapatkan pengetahuan tentang kehidupan Islam. Kedua, tujuan politik. Walau berisiko tinggi, Snouck berhasil menilai pengaruh Mekkah atas Hindia Belanda, Aceh khususnya.

Dalam mengamati perilaku para tuanku di Dalam (keraton) dan membandingkannya dengan pandangan masyarakat. Hurgronje menggambarkan suasana Dalam secara jauh dari menyenangkan; sedikit persengketaan mengenai penampilan bocah penari seudati yang berdandan seperti wanita dan menimbulkan

${ }^{19}$ Snouck, De Atjehers, dalam Kata Pengantar, INIS 
kaumhomop seks, dapat memicu peperangan yang berlarut-larut. Para Sultan disosokkan sebagai penguasa yang semena-mena mengambil apa saja yang diinginkan dari rakyat, seka menghukum siapapun yang melawan terhadap perbuatan semenamena yang tanpa batas. Anak-anak perempuan dan rakyat kecil menjadi korban hawa nafsu mereka. Rakyat sama sekali tidak berdaya terhadap perbuatan jahat raja dan puteranya. Sementara para uleebalang tidaklah dapat diharapkan membantu mereka sama sekali. Maka berlakulah hukum alamiah, yakni balas dendam. Juga para abdi raja, sebagian besar adalah orang yang bertabiat jelek, yang suka melarikan diri ke dalam untuk menyelamatkan diri dari ancaman balas dendam. Dari sini, Snouck berkesimpulan bahwa tidaklah aneh bila penghormatan secara tradisional yang diberikan oleh rakyat kepada para raja dan keturunannya, dingkapkan dengan cara yang "agak aneh"; lebih banyak diungkapkan dengan kata-kata atau bentuk yang tidak mengandung arti, bukannya diwujudkan dalam perbuatan. ${ }^{20}$

Sebenarnya sebelum keberangkatannya ke Aceh yang kemudian melambungkan namanya ini Snouck pernah mencoba untuk ke Aceh sebelumnya. Yakni Setelah kembali ke Leiden selama dua tahun ${ }^{21}$ kemudian ia menawarkan diri untuk ditugaskan ke Aceh. Jabatan lektornya dilepas pada pertengahan Oktober 1887. Proposal penelitian kepada Gubernur Jenderal segera diajukan pada 9 Februari 1888. Niatnya didukung penuh oleh Direktur Pendidikan Agama dan Perindustrian (PAP), juga Menteri Urusan Negeri Jajahan. Proposalnya pun berjalan tanpa penghalang. Snouck segera berangkat. Tempat yang dituju adalah Aceh. Sayang, begitu sampai di pelabuhan Penang (Malaya), Gubernur Van Teijn melarangnya masuk Aceh, pada 1 April 1889.

Alasannya, Snouck bergaul dengan kaum pelarian dan berusaha masuk ke Aceh secara gelap. Akhirnya Snouck meluncur ke Batavia (Jakarta) dan tiba pada 11 Mei $1889 .^{22}$

${ }^{20}$ Snouck, De Atjehers, I: 105-108

21 Snouck memasuki Timur Tengah melalui pelabuhan Jeddah kemudian ke Mekah, dalam jabatan Lektor setelah jabatan Lektor untuk ilmu agama Islam pada sebuah lembaga kotapraja Leiden, pada tahun 1884-1887. Kemudian terpaksa pulang ke Leiden secara mendadak karena, tepat menjelang pelaksanaan ibadah haji, karena identitasnya dibocorkan oleh pihak konsul Perancis saat itu usianya 28 tahun. Di Leiden ia bergaul akrab dengan Wilken yang berusia sepuluh tahun lebih tua.

${ }^{22}$ Sebenarnya, Snouck berangkat ke Aceh (1889) untuk sebuah tugas yang sangat penting atas perintah Belanda. Perjalanan ini sangat rahasia, ia naik kapal pos Inggris sampai ke pantai Sumatra. Melalui Pelabuhan Penang ia masuk pedalaman Aceh sampai ke istana sultan dengan cara memanfaatkan tradisi menghormat sesama Muslim yang dikenalnya di Mekkah. Tapi di pihak lain, perjalanan itu dianggap mata-mata oleh militer Belanda di Aceh. Mereka keberatan, maka ia harus 


\section{PERANG ACEH}

Dalam peta geografis, Aceh berada di jalur strategis perdagangan dunia, Selat Malaka. Snouck, melalui Atjeh Verslag dan De Atjeher, Snouck memberi gambaran mengenai posisi yang layak dikuasai tersebut, khususnya setelah berhasil memetakan potensi penduduknya, sehingga konflik terjadi di antara penduduk pribumi Aceh, dan kekuasaan mereka terselamatkan.

Perang Aceh merupakan fenomena tersendiri bagi Belanda, selama 16 tahun pemerintah kolonial harus menanggung biaya yang sama sekali tidak sebanding dengan wilayah tahkukan dan perlengkapan musuh yang harus dihadapi. Perang ini menempatkan Belanda pada keterpurukan. Malu karena tak bisa menguasai Aceh, Belanda sebagai bangsa yang sudah berhasil menaklukkan beberapa bangsa besar di dunia penjajahan, ternyata, kecerdasan mereka yang dianggap lambang modernitas saat itu, terpaksa kalah dengan sebuah kerajaan yang pernah terpuruk dalam sejarah.

Secara militer, bagaimana pun Belanda lebih unggul. Mereka memiliki senjata mutakhir yang digambarkan dengan senapan, tentara elite yang direpresentasikan oleh Marechaussee dan tentu saja strategi perang modern. Sementara melihat perlawanan rakyat Aceh saat itu, sepertinya mustahil untuk ditaklukkan. Padahal Aceh, bagi Belanda hanyalah daerah kecil dengan senjata seadanya yang dipimpin seorang uleebalang. Maklumat perang yang dikumandangkan oleh Nieuwenhuyzen, Komisaris Gubernemen Hindia Belanda, menjadi sangat penting, di mana ia melakukannya dari sebuah kapal perang, Cidatel van Antwerpen pada tanggal 26 Maret 1873. Hari itu, Rabu, mereka berlabuh sekitar kawasan Ulee Lheue. Sejak penyerangan 8 April 1873 Setelah lebih dahulu dimaklumatkan perang melalui Pantai Cermin dan langsung bisa menguasai Majid Raya Baiturrahman. Belanda mengerahkan 3.198 tentara. Sebanyak 168 di antaranya adalah para perwira. Namun pasukan mereka ternyata tak mampu bertahan, sebanyak 45 orang mati, hampir 500 orang luka-luka. Bahkan Kohler, sang panglima pasukan Marechaussee ini pun

dipulangkan. Di Batavia, Snouck bekerja sebagai pegawai pemerintah. Snouck langsung akrab dengan pribumi Batavia, termasuk ulama. Ini membuat Direktur PAP terkesan dan mendesak Gubjen C. Pijnacker Hordijk agar mengabulkan permohonan penelitian itu. Keluarlah beslit yang mengizinkan Snouck melakukan penelitian selama dua tahun, sejak 16 Mei 1889, disusul beslit Raja Belanda pada 22 Juli 1889. Bahkan ia diangkat menjadi Penasihat urusan Bahasa-Bahasa Timur dan Hukum Islam sejak 15 Maret 1891. 
akhirnya mati pada 14 April 1873, karena ditusuk pejuang Aceh.

Sepuluh hari kemudian, perang berkecamuk di mana- mana. Yang paling besar saat merebut kembali Masjid Raya Baiturrahman, yang dibantu oleh beberapa kelompok pasukan. Laskar-laskar rakyat ini terdiri dari para penduduk di wilayahwilayah pedalaman seperti Peukan Aceh, Lambhuek (Lambuk), Lampuuk, Peukan Bada, sampai Lambada, Krueng Raya. Beberapa ribu orang juga berdatangan dari Teunom, Pidie, Peusangan, dan beberapa beberapa wilayah lain. Sebanyak 70.000 rakyat Aceh menjadi korban. Hampir 35.000 pasukan Belanda dikorbankan dalam perang itu. Sedangkan pasukan Marechaussee yang merupakan pasukan elit dalam korps tentara pendudukan Belanda, ternyata tak dapat berbuat banyak dan justru sebaliknya mereka malah turut menjadi korban.

Namun seperti apapun rakyat Aceh bertahan, secara de facto kerajaan telah dikuasai, dan Belandamengklaimtelahmenundukkan negeri serambi Mekah, meski secara de Jure orang-orang Aceh masih tetap merdeka di bawah kendali pemimpinpemimpinnya sendiri. Maka di sinilah peran seorang Snouck menjadi sangat dominan dalam strategi politik kolonial. kehadirannya menandai era baru bagi perang yang telah berlangsung hampir 20 tahun tersebut.

Setelah ia mendarat di Aceh sebagai penasehat pemerintah, ia segera memerintahkan ekspansi militer dengan gagah ke segenap penjuru wilayah tahlukan terhadap para pejuang gerilya setelah kerajaan Aceh menguasai Masjid Baiturrahman dikuasai, namun akhirnya Snouck terpaksa mengubah taktik militernya. Memang pada 1904, kesultanan Aceh yang saat itu diperintah oleh Sultan Muhammad Daud Syah (memerintah sejak 1874) menyatakan takluk. Tapi persoalan Aceh tetap tak selesai. Sehingga Snouck terpaksa membalikkan metode, dengan mengusulkan agar di Aceh diterapkan kebijakan praktis yang dapat mendorong hilangnya rasa benci masyarakat Aceh karena tindakan penaklukkan secara bersenjata. Inilah yang menyebabkan sejarah panjang ambivalensi dialami dalam menyelesaikan Aceh. Snouck pula yang menyatakan bahwa takluknya kesultanan Aceh, bukan berarti seluruh Aceh takluk.

Terbukti kemudian Sultan Muhammad Daud Syah yang dinyatakan oleh Snouck sebagai tidak memiliki arti politik, ternyata tetap menunjukkan perannya sebagai pemimpin Aceh. Sebab ketika terjadi serangan gerilya laskar rakyat atas Kutaraja 
tahun 1907, setelah berbulan-bulan mengadakan penelitian, pemerintah justru memperoleh kesimpulan bahwa ternyata sang Sultan-lah yang merencanakan serangan tersebut. Akhirnya, bentuk penaklukkan harus terbelah, di mana Snouck merupakan tokoh yang paling penting di balik semuanya. Selama proses penahlukan dijalankan, Belanda telah menuai untung. Kepemimpinan Aceh terbagi, satu sama lain saling curiga dan bertentangan.

Di sini akhirnya Snouck justru mementaskan kembali, sebuah "drama" yang ditertawakannya. Dari Hikyat Pocut Muhamat (epos Pangeran Muhammad) yang menceritakan tentang perang saudara antara penguasa pribumi yang beragama Islam dan berjiwa ksatria dengan dibantu oleh para ulama setempat, melawan seorang bangsawan keturunan Arab (keturunan Nabi/Sayid) yang berusaha merongrong kebesaran raja-raja setempat, namun banyak dihianati oleh para uleebalang pembantunya. Agak unik, meski sang Sayid (Jeumalay/Jamalul-Alam) kalah dan terpaksa keratonnya harus dihancurkan, namun ia masih diberi beberapa konsesi. Justru para pendukung yang menghianatinya harus menanggung 'afat yang tak terelakkan. Snouck sangat memanfaatkan kepercayaan rakyat Aceh bahwa siapapun yang menghianati keturunan Nabi, akan tertimpa bencana dari Allah.

Dalam proses pemetaannya, Snouck berangkat dari jaringan ulama sehingga ia menjadi bagian sejarah terpenting dalam perjalanan perlawanan Aceh terhadap Belanda. Ia kemudian mendekati ulama untuk bisa memberi fatwa agama dengan didasarkan pada politik devide et impera. Demi kepentingan keagamaan, ia berkhutbah untuk menjauhkan agama dan politik, karena Islam (agama) politik akan berpotensi terlaksananya ide pan-Islamisme. Kemudian memperdaya dan mengaduk konsep alQuran dan azimat. Sedangkan untuk adat, ia justru mendorong orang-orang untuk memperbesar pelaksanaan ritual adat-adat yang bermasalah, yang dalam konteks Aceh dapat disebut syirik, bid'ah, dan yang semacam dengannya. Kelebihan Snouck, setidaknya tampak pada keberhasilan membuat peta konflik antar orang Aceh sendiri, sehingga konflik tersebut sangat menguntungkan mereka sebagai penjajah.

Namun Snouck rupanya terlampau pendek menganalisa, apa yang disebutnya sebagai perilaku non-Islam yang terdapat dalam adat Aceh, seperti pemakaian jimat, ilmu kebal dan lain-lain, memalingkannya pada kesimpulan bahwa suatu kondisi umum tersebut merupakan indikasi negatif dan hanya menghasilkan penilaian yang 
berat sebelah. Banyak ditemukan upaya-upaya dari ulama untuk memberantas praktekpraktek non-Islam di Aceh, dikukuhkannya sebagai pertentangan an-sich yang perlu segera "ditengahi". Snouck menafikan upaya tersebut sebagai suatu proses bertahap dalam perkembangan masyarakat.

Ia mematahkan perlawanan para ulama dengan mengadu mereka melawan parauleebalang; menciptakan opini bahwa yang berhak memimpin Aceh bukanlah uleebalang, melainkan ulama yang dekat dengan rakyat kecil. Dari sini komponen paling menentukan sudah pecah, rakyat berdiri di belakang ulama sementara Belanda mengambil posisi sejajar dengan uleebalang yang sedang merasa disaingi oleh ulama. ${ }^{23}$ Sementara itu ia justu menulis surat kepada Gubernur jenderal Hindia Belanda pada tanggal 18 Januari 1894, "Hubungan ulama dan uleebalang di Aceh menunjukkan rasa benci yang didorong oleh kepentingan pribadi”. Karenanya ia menganjurkan agar pemerintah Hindia Belanda tidak mudah percaya kepada pernyataan takluk para uleebalang, "Sebab di Aceh tidak terdapat ajaran adat yang diakui secara umum. Sebaliknya terdapat kekacauan yang tak ada habis-habisnya." Sebuah strategi khas kolonial, di mana untuk melaksanakannya tentu membutuhkan proses panjang penajaman pengetahuan. Snouck secara langsung, dengan berbagai cara berupaya agar dapat masuk ke mana-mana. Bahkan ia telah memulainya semenjak masih di Mekkah hingga Aceh dan Batavia. Gelarnya sebagai Syaikh al-Alim di Jawa dan Sumatera memungkinkannya menyelidik dengan leluasa dan mendapat simpati beberapa ulama pribumi -yang tidak mau ambil pusing atas kolonialisme- pada zamannya.

Di mana dalam pandangan Snouck, pada saat Belanda datang ke Aceh, seorang sultan atau keturunan sultan memiiki kemauan keras dan ide khas yang cemerlang untuk memimpin dan mengobarkan perlawanan mati matian melawan Belanda. Dengan demikian raja seperti ini tidak dapat diremehkan. Karena tipe pemimpin seperti ini akan jauh lebih mudah berhasil dari pada orang lain untuk menyatukan rakyat Aceh yang terpecah belah. Demikian juga dengan para ulama yang mampu mengobarkan perang suci, mereka akan mampu merebut kekuasaan dari tangan para uleebalang, dan

${ }^{23}$ Strategi ini mirip sekali dengan kebijakan Belanda yang berlaku di Minangkabau, dengan mempertentangkan antara kaum Paderidan Kaum Adat, Belanda semakin mengukuhkan kedudukannya sebagai penguasa dengan memosisikan diri menjadi penengah. Bahkan di sisi lain ia mendekati para Habib keturunan Arab yang kebetulan kurangt dekat dengan ulama-ulama pribumi. Lihat, Buya Hamka, Dari Perbendaharaan Lama, Jakarta : Pustaka Panjimas. 
hasilnya : sama sekali tidak dapat diremehkan oleh Belanda. Bahkan jika seorang raja memiliki kemampuan ganda, yakni sebagai ulama dan pengemban tradisi kebesaran Aceh, berhasil menyimpulkan simpati rakyatnya, maka Belanda akan menghadapi kengerian yang maha dahsyat. Tak sepasukan Belanda pun akan dapat selamat dari kedahsyatan mereka.

Namun Snouck dapat sedikit bernafas lega ketika ia berpikir bahwa anggapan seperti ini sebenarnya jauh dari kenyataan. Seorang raja Aceh yang dengan gigih membela kepentingan rakyatnya dan menjunjung martabat agama, merupakan fenomena yang tidak dapat dijelaskan, sekalipun oleh rakyat Aceh sendiri, kecuali hanyalah sebagai sebuah kekuasaan Tuhan yang menakjubkan dan tanpa batas. Karenanya, dapat disiasati bagaimana agar unsur-unsur kekuatan politik Aceh ini terpecah dan bahkan saling bermusuhan. Oleh karena kondisi geografis Aceh yang berpantai luas dan bergunung-gunung tinggi pula, maka kemudian Snouck membedakannya dalam dua kategori, yakni orang-orang dataran rendah dan dataran tinggi (orang gunung). Ia mengungkapkan strategi ini karena memahami karakter masing-masing penduduk yang berbeda :

Unsur-unsur yang kurang baik tidak pernah ditemukan bersama untuk mengatur perlawanan yang kuat terhadap serbuan asing seperti didataran rendah, di daerahyang berdekatan dengan dalam, sesungguhnya orang di sana, banda, memiliki

"kearifan duniawi" dan tidak duson (tidak berpengetahuanseperti orang desa) sebagaimana di dataran tinggi. Mereka telah dimanjakan oleh sejarah, agak angkuh terhadap semia pikiran penguasaan oleh pihak asing. Namun karena banyakberhubungan dengan orang asing, baik Muslim maupun bukan, mereka cenderng bersikap lunak dan menjauhkan diri dari kepercayaan naif, bahwa senjata orang Islam umumnya dan rakyat Aceh khususnya, tidak terkalahkan; hal yang menjiwai orang di dataran tinggi yang masih setengah liar. Kelompok pejang hanya sedikitsekali merekrut daerah di dekat pantai, mereka yang ditasbihkan untuk mati. Akan tetapi ada dua hal yang menncegah kebanyakan mereka untuk mengungkapkan hal itu. Pertama adalah perpecahan intern yang besar terdapat di kalangan mereka dan mudah menyebabkanseorang penasehat yang suka damai dinyatakan sebagai penghianat oleh lawannya. Kedua, bahwa orang dari dataran tinggi tidak akan setuju 
dengan perundingan, dan meskipun mereka lamban sekali dalam memberikan bantuan aktif di luar batas daerah mereka, siapapun yang berkomplot dengan kafir juga akan diperlakukan sebagai kafir. Bagaimanapun karena sifat orang dataran rendah yang lebih tenang dan suka damai, oleh orang dataran tinggi mereka dikenal sebagai penakut.

Snouck menilai bahwa perlawanan rakyat Aceh terhadap kumpeni Belanda sebagai nafsu perang yang bodoh. Apalagi ia sengaja memuji para pembelot yang menjadi sekutu pemerintah kolonial. Di dalam verslag dan nasehat politiknya Snouck memandang perlawanan sebagai ekspresi anarki dan ketidakpatuhan pada hukum.

Mengenai kebijakannya yang cenderung melunak pasca penahlukan kesultanan Aceh yang sangat mengesankan, Snouck sebenarnya memainkan dua peran ganda di balik layar, yakni peran militer sekaligus sipil. Karenanya, kebijakan apapun yang dikeluarkan oleh pemerintah Belanda, baik berkenaan dengan ekspansi militer maupun pendekatan negosiasi sipil adalah karena analisanya atas biaya yang harus ditanggung dalam menahlukkan Aceh. Sekedar contoh adalah Van Heutsz, seorang petempur murni, komandan Marechaussee yang bertanggungjawab atas keamanan Aceh setelah kesultanan ditahlukkan. ${ }^{24}$ Di mana ia harus merevisi kebijakan pertamanya, yang tentunya dijalankan atas nasihat Snouck; mematahkan perlawanan dengan keras. Namun ternyata ia harus menggunakan nasihat kedua, yang beranggapan bahwa pelumpuhan perlawanan dengan kekerasan hanya akan melahirkan implikasi yang tambah sulit diredam.

Berawal dari kesadaran atas kebencian rakyat Aceh terhadap kehadiran pemerintah Belanda yang sangak kuat mengakar, menasehati gubernur militer di Aceh agar tidak melakukan pembakaran rumah dan perampasan harta penduduk di daerahdaerah yang menjadi target operasi pasukan Marechaussee. Ia berharap agar kesejahteraan rakyat Aceh di daerah-daerah takhlukan diperhatikan oleh pemerintah. Kemampuan pemerintah untuk mengambil hati rakyat, diperlukan untuk membangkitkan ketertundukan mereka. Sehingga, untuk mengatasi ketidakpopuleran Pemerintah Hindia Belanda, ia menyarankan agar pemerintah bersikap bersahabat dengan kalangan ulama yang berpikiran "moderat". Peran uleebalang diperbesar tanpa

\footnotetext{
${ }^{24}$ Van Heutz, jenderal yang pernah bertugas di Aceh ini kemudian menjabat Gubernur Jenderal Hindia Belanda (1904-1909).
} 
mengurangi simbol-simbol keagamaan, seperti pembangunan Masjid Baiturrahman, sehingga posisi pemerintah semakin kuat. Kebijakan ini diharapkan mempersempit pengaruh ulama yang berpola pikir "radikal".

Di sisi lain Snouck menganjurkan kekerasan senjata perlu dilakukan untuk mengalahkan rakyat Aceh yang berdiri di belakang ulama "radikal". Menempatkan etnis Arab sebagai kelompok pinggiran seperti halnya etnis China. ${ }^{25}$ Warga keturunan Arab dipisahkan dari kesatuan bangsa Indonesia yang terdiri atas berbagai suku. Saran bertindak keras itu dilakukan Van Heutsz.

Namun Nasehat pertama ini tampaknya memicu konflik antara Snouck dengan Gubernur Militer, Van Heutsz. Snouck menginginkan agar Aceh diperintah oleh gubernur sipil dan mengusulkan pengurangan pasukan Marechaussee serta penggantian peran-peran militer dengan polisi dan penegakan hukum sipil. Sementara van Heutsz dan para pengikut di kalangan perwira tetap berkeras bahwa kekuasaan militer harus tetap dilanggengkan. Toh akhirnya Snouck, dengan beraneka tipu dayanya telah menorehkan sejarahnya sendiri, jalan "tanpa perang" untuk Aceh, tak hanya mampu menaklukkan, tapi juga sanggup memetakan masyarakat Aceh secara "sempurna"; semua elemen terikat erat dengan kepentingan Belanda: ulama, golongan menengah, sampai rakyat jelata. Di mana dua sisi kefanatikan telah menyatu dalam dirinya. Ego pribadi melawan supremasi militer dalam pemerintahan bangsanya di negeri-negeri jajahan dan ambisi politiknya untuk mencabik-cabik dan mengubur dalam-dalam "Islam politik" yang sangat dimusuhinya, mengantarkan karirnya sebagai seorang ilmuwan orientalis sekaligus insan politik yang sangat ambisius mengalahkan lawan-lawan dihadapannya.

Penaklukan Aceh menjadi ujian berat bagi hipotesa Snouck untuk membasmi kaum ulama dan membenturkannya dengan uleebalang sebagai pemuka adat. Tampaknya Snouck memaknai dialektika adat dan agama hanya sebagai dua elemen yang saling menunggangi. Ia lupa bahwa ulama bukanlah semata-mata pembuat legitimasi kekuasaan uleebalang. Sebagaimana juga di Jawa, para ulama dan priyayi juga merupakan seteru politik yang senantiasa berkompetisi. Ulama menjadi penentang

25 Baca, Mr. Hamid Algadri dalam C. Snouck Hurgronje: Politik Belanda terhadap Islam dan Keturunan Arab, Penerbit Sinar Harapan, 1984 
terhadap praktek adat yang betentangan dengan ajaran Islam. Snouck luput memerhatikan peran ulama sebagai kekuatan dinamis yang sekali waktu menggerakkan masyarakat untuk menetang ataupun mengimbangi kebijakan uleebalang. Peran inilah yang menempatkan posisi ulama sangat penting dalam menggerakkan perlawanan rakyat Aceh, khususnya dengan memainkan doktrin sahid dan kebahagian akhirat.

Rekomendasi Hurgronje kepada pemeritah kolonial menyangkut penahlukan Aceh dengan cara membenturkan posisi kaum ulama dan kelompok aristokrat, uleebalang (uleebalang), telah melahirkan suatu "realitas baru" di tengah masyarakat Serambi Mekah. Ketika rekomendasi itu dijalankan, dan pemeritahan kolonial menggandeng pihak uleebalang di satu sisi tetapi memerangi kaum ulama di sisi lain, meningkatlah sistem feodal (kepriyayian) di kalangan masyarakat. Lebih dari itu, kebijakan tersebut memperlebar jurang pemisah antara kelompok aristokrat pribumi dengan ulama yang justru didukung oleh masyarakat luas. Dari sini, pelajaran yang dapat kita simak dari pendekatan tradisi orientalisme yang digunakan Hurgronje adalah pentingnya bahasa sebagai alat menguak kehidupan masyarakat Aceh dengan penekanan pada kehidupan keagamaan. Di samping itu diperlukan suatu pandangan bahwa penelitian langsung di lapangan merupakan suatu keharusan jika kita ingin benar-benar memahami apa yang sesungguhnya terjadi.

Meski bagi sebagian orang, rekomendasi Snouck dengan segala akibatnya di sini dianggap berhasil mengukuhkan kekuasaan pemerintahan kolonial di tanah Aceh, tetapi gagasan dan obsesinya untuk menciptakan apa yang dia sebut "asosiasi budaya" antara pribumi dan Belanda gagal total. Di sini "cita-cita besar" Hurgronje adalah menciptakan suatu kebudayaan universal, yang dapat mempersatukan umat manusia atas dasar "cinta pada sesama". Namun, langkah yang ia tempuh justru keliru. Bagi Hurgronje, satu-satunya jalan untuk merealisasikan obsesinya itu adalah bagaimana membawa dunia Islam dan pengaruhnya menjadi modern melalui kebudayaan Barat. Ini pelajaran berharga lain yang bisa dipetik dari Hurgronje. Arogansi keilmuan dan perasaan superioritas yang tertanam kuat dalam dirinya itu malah menjadi bumerang bagi obsesinya sendiri.

Kegagalan obsesi ini menempatkan laporan-laporan Snouck sebagai narasi 
yang sarat pesan rasial dan moralitas liberal diarahkan untuk membungkam berbagai kritik yang muncul di Eropa soal perperangan di Aceh yang sudah memaka seratus ribu lebih korban jiwa, waktu yang begitu panjang dan menghabiskan ratusan juta gulden. Narasi ini hanya sedikit berbeda dengan berbagai laporan amatir kelasi Portugis pada tiga abad sebelum dia menulis. penggambaran penduduk Nusantara sebagai pemakan manusia dan masih berekor seperti kera. Sistem sosial dan kenegaraan di Nusantara dipandang jauh terbelakang, tak memiliki persatuan dan tidak ada pemerintahan yang utuh. Khusus mengenai Aceh, Snouck menekankan pertikaian yang terus menerus dalam pergantian raja-raja dan perebutan kekuasaan antar uleebalang. Ia mengajukan kesimpulan bahwa kemunduran kerajaan Aceh selama 30 tahun sebelum perang Aceh dimulai adalah situasi yang sah untuk menahlukkan negeri tersebut.

Penaklukan Aceh akhirnya harus dipahami bukan hanya dalam konteks lokal. Snouck Hurgronje, sebagai orang yang sangat menentukan berhasilnya penaklukkan Belanda di Aceh, harus dilihat pula sebagai kepentingan global, dengan menyebarnya ideologi kapitalisme di seluruh dunia. Barangkali, apa yang terjadi di Aceh merupakan satu sasaran antara, saat kemudian, kapitalisme memang menjadi pemenang. Seorang sarjana tentang Islam ternyata lebih hebat dibanding seorang serdadu dalam menganjurkan kebijaksanaan yang tak kenal ampun terhadap kaum ulama. Jadi, seberapa pun besarnya biaya yang dikeluarkan untuk pendidikan dan penelitian Snouck oleh Belanda, tak ada yang patut ditangisi, apalagi sampai disesali, karena sumbangsih Snouck untuk Belanda, jauh lebih besar dari biayai yang telah dikeluarkan. Sebagaimana halnya T.S. Raffles yang juga berusaha memahami bangsa-bangsa Pribumi, alam hidup dan lingkungan mereka, untuk mengembangkan potensi sumber daya alam dan manusianya, sebagai langkah kebijakan antara, dalam membangun imperium Britania Raya. Bagi Snouck, cukuplah baginya menulis surat-surat nasihat kepada Gubernur Jenderal Hindia Belanda tentang bagaimana menjinakkan musuhmusuh gubermen.

Tulisan ini tentu hanya setitik noktah kecil dari riuhnya pembicaraan, kekaguman dan kemarahan tentang Snouck Hurgronje. Memberikan gambaran utuh 
sosok Snouck Hurgronje ${ }^{26}$ tidaklah mencukupi dalam waktu pendek, karena hasilnya hanyalah parsial. Penulis teringat dengan seorang teman di sana, seorang wartawan pribumi asli Aceh. Menurutnya, "Jika kita ingin mengetahui tentang Aceh maka lihat dan amatilah sendiri, bagaimana kami menjalani dan memaknai hidup. Jangan mempercayai penulis-penulis(paraantekkolonial-red)yang sangat merugikan kami itu. Karena mereka tidaklah mampu memahami karakter kami dengan berlapang dada”. Kita mafhum bahwa semua bangsa di dunia punya gaya tersendiri untuk menyatakan rasa muak, jijik dan jengkel kepada seseorang, kelompok apalagi kepada penjajah kafir, musuh poitik sekaligus musuh agama.

Sedikit cerita, konon Bangsa Belanda mengakui melalui Snouck, bahwa orangorang Aceh mempunyai superiority complex. Kendati yang dimaksud superiority complex oleh Snouck Hurgronje ialah penyakit jiwa, sebab mereka melihat Belanda itu sebagai Kafir dan "Engkong putéh, silaklim” (orang putih zalim). Namun justru ketika sebutan-sebutan ini merakyat, maka Belanda sama sekali tidak mempunyai ruang dalam hati bangsa Acheh. Sehingga rakyat Aceh dalam kondisi apapun tetap melawan musuh (penjajah) meskipun pemimpin mereka ditangkap, meninggal atau dibunuh. Di samping itu, orang-orang Aceh sangat membenci pengkhianat/mata-mata (cuak Belanda). Pada zamannya, cuak diidentifikasikan sebagai orang-orang yang mengambil manfaat dari kolonialisme Belanda.

Untuk menelusuri karateristik rakyat Aceh dalam rentang sejarah dan falsafah berpikir merdeka, sekurang-kurangnya kita harus dapat mendengarkan dengan hati mengenai falsafah pelayan warung kopi, pengunyah sirih serta pedagang ayam dan bèbèk. Mereka digambarkan sebagai rakyat jelata yang tetap melawan, meski tak lagi memiliki senjata. Mereka melakukan tindakan- tindakan "kontra budaya" untuk menentang pendudukan oleh bangsa asing. Masing-masing baik pelayan warung kopi, pengunyah sirih serta pedagang ayam dan bebek memiliki cara yang berbeda untuk mengungkapkan ketidaksetujuannya pada kolonialisme, hingga dari sinilah bermula

${ }^{26}$ Pengembaraannya di Hindia Belanda berakhir pada 1906 dan kembali ke Belanda. Pada 1910, di Belanda, ia menikah dengan Ida Maria, putri seorang pensiunan pendeta di Zutphan, Dr AJ Gort. Setelah dikukuhkan sebagai guru besar Universitas Leiden pada 1913 (tiga tahun setelah menikah), ia menekuni profesi sebagai penasihat Menteri Urusan Koloni. Pekerjaan ini diemban hingga akhir hayatnya, 16 Juli 1936. 
anggapan oleh para penjajah bahwa penduduk Aceh hanyalah sekumpulan orang-orang sinting yang tidak "tahu diuntung" dan tidak dapat menghargai modernisasi tanpa pernah menanyakan mengapa mereka melakukan tindakan- tindakannya.

Di sisi lain, dalam beberapa tradisi rakyat Aceh percaya pada ketajaman indera pemimpinnya. Bahwa Tjut Njak Diën memiliki indera yang sangat tajam. Kepada pengawalnya, Pang Leubé, Beliau berkata: "Saya mencium bau penjajah Belanda di sekeliling saya". Memang benar, Pang Leubé "berbau Belanda". Akhirnya si Leubé dibunuh oleh Tjut Njak Diën dengan rencongnya sendiri. Sebagai penutup, marilah kita sejenak merenungkan tentang sejarah yang telah berlalu dan hanya menyisakan catatanatatan dari peristiwa masa silam tersebut. Bahwa, dalam kasus Cristian Snouck Hurgronje dan kehadirannya di Aceh. Kita dapat menengarai timbulnya ekses berkepanjangan yang hingga kini masih harus dipikul oleh masyarakat Aceh dalam berbagai bentuk keniscayaan lainnya hingga zaman pemerintahan NKRI. 